\title{
SOME CONSIDERATIONS IN THE HANDLING OF FLUORINE AND THE CHLORINE FLUORIDES
}

\author{
R. L. Farrar, Jr. \\ E. J. Barber \\ Enrichment Technology Division \\ Oak Ridge Gaseous Diffusion Plant
}
Presented to the Materials Research Council
Defense Advance Research Projects Agency, DOD
July 13, 1979
La Jolla, California

\section{UNION CARBIDE CORPORATION NUCLEAR DIVISION Oak Ridge, Tennessee}

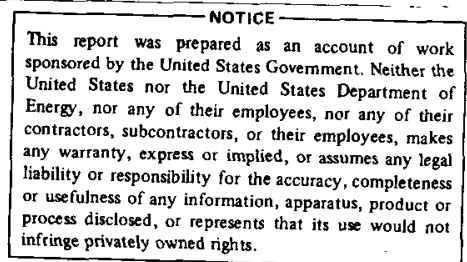

Prepared for the U. S. Department of Energy Under U. S. Government Contract W-7405 eng 26 


\section{DISCLAIMER}

This report was prepared as an account of work sponsored by an agency of the United States Government. Neither the United States Government nor any agency Thereof, nor any of their employees, makes any warranty, express or implied, or assumes any legal liability or responsibility for the accuracy, completeness, or usefulness of any information, apparatus, product, or process disclosed, or represents that its use would not infringe privately owned rights. Reference herein to any specific commercial product, process, or service by trade name, trademark, manufacturer, or otherwise does not necessarily constitute or imply its endorsement, recommendation, or favoring by the United States Government or any agency thereof. The views and opinions of authors expressed herein do not necessarily state or reflect those of the United States Government or any agency thereof. 


\section{DISCLAIMER}

Portions of this document may be illegible in electronic image products. Images are produced from the best available original document. 
TABLE OF CONTENTS

$\underline{\text { Page }}$

Introduction $\ldots \ldots \ldots \ldots \ldots \ldots \ldots \ldots \ldots \ldots \ldots \ldots \ldots \ldots \ldots \ldots \ldots \ldots \ldots \ldots$

Summary $\ldots \ldots \ldots \ldots \ldots \ldots \ldots \ldots \ldots \ldots \ldots \ldots \ldots \ldots \ldots \ldots \ldots \ldots \ldots \ldots \ldots \ldots$

Properties of the Materials $\ldots \ldots \ldots \ldots \ldots \ldots \ldots \ldots \ldots \ldots \ldots \ldots \ldots \ldots . \ldots$

Physical and Chemical Properties $\ldots \ldots \ldots \ldots \ldots \ldots \ldots \ldots \ldots \ldots . \ldots 7$

Toxicological Properties ......................... 9

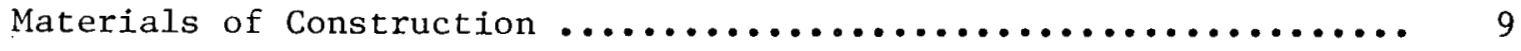

Metals $\ldots \ldots \ldots \ldots \ldots \ldots \ldots \ldots \ldots \ldots \ldots \ldots \ldots \ldots \ldots \ldots \ldots \ldots \ldots \ldots \ldots . . \ldots$

Other Materials $\ldots \ldots \ldots \ldots \ldots \ldots \ldots \ldots \ldots \ldots \ldots \ldots \ldots \ldots \ldots \ldots \ldots . \ldots . \ldots . \ldots$

Safe Practices in Design and Operation $\ldots \ldots \ldots \ldots \ldots \ldots \ldots \ldots \ldots$

Disposal Methods and Problems $\ldots \ldots \ldots \ldots \ldots \ldots \ldots \ldots \ldots \ldots \ldots \ldots \ldots \ldots$

Soda Lime Traps $\ldots \ldots \ldots \ldots \ldots \ldots \ldots \ldots \ldots \ldots \ldots \ldots \ldots \ldots \ldots \ldots \ldots \ldots . \ldots . \ldots \ldots$

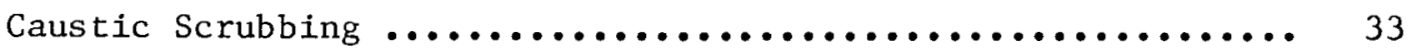

Problems with Carbon and Graphite ................... 33

Some Explosive Reactions and Explosive Situations ............ 36

Lab Studies on Explosive Mixtures $\ldots \ldots \ldots \ldots \ldots \ldots \ldots \ldots \ldots \ldots \ldots . \ldots \ldots$

Case Histories of Lab Scale Explosions ................ 41

Conclusion $\ldots \ldots \ldots \ldots \ldots \ldots \ldots \ldots \ldots \ldots \ldots \ldots \ldots \ldots \ldots \ldots \ldots \ldots \ldots \ldots \ldots \ldots$ 

SOME CONSIDERATIONS IN THE HANDLING OF FLUORINE
AND THE CHLORINE FLUORIDES

R. L. Farrar, Jr. E. J. Barber

Union Carbide Corporation, Nuclear Division ${ }^{1,2}$

\section{INTRODUCTION}

Fluorine is the most powerful oxidizing agent of all the chemical elements. Safety in the handling of fluorine and the chlorine fluorides requires a knowledge of the properties of the materials and careful planning of the experiments or operations prior to their being undertaken. Fluorine has been used in large quantities on an industrial and laboratory scale in atomic energy operations for over 30 years, and no lost time accident or disabling injury has ever occurred in its handling. With a safety record of this magnitude, one might be tempted to say that the hazard had been overstated. The risk is real, however, and complacency would be our worst enemy. Good safety procedures have produced results in the past, and they can continue to minimize the risk in using this material. The safety record for the use of the chlorine fluorides is not as good as that with fluorine, especially among research and development personnel.

This paper seeks to call attention to several areas of possible difficulty and the specific subjects which will be covered are shown in Figure 1. We need to be aware of the properties of these materials, their physical and chemical properties as well as their toxicological properties. We need to choose proper materials of construction to have a safe system; we will consider some of the factors in design and operation of safe systems. Disposal of excess materials must be accomplished safely, and we will discuss some of the disposal problems. Finally we will look at some laboratory studies on explosive reactions and cite some case histories.

\footnotetext{
Inion Carbide Corporation, Nuclear Division, operates the Oak Ridge and Paducah Gaseous Diffusion Plants for the United States Department of Energy. The Portsmouth Plant is operated for DOE by the Goodyear Atomic Corporation.

${ }^{2}$ This document has been approved for release in accordance with classification and release procedures prescribed by the United States Department of linergy.
} 
Figure 1

SAFE HANDLING OF FLUORIDE AND THE CHLORINE FLUORIDES

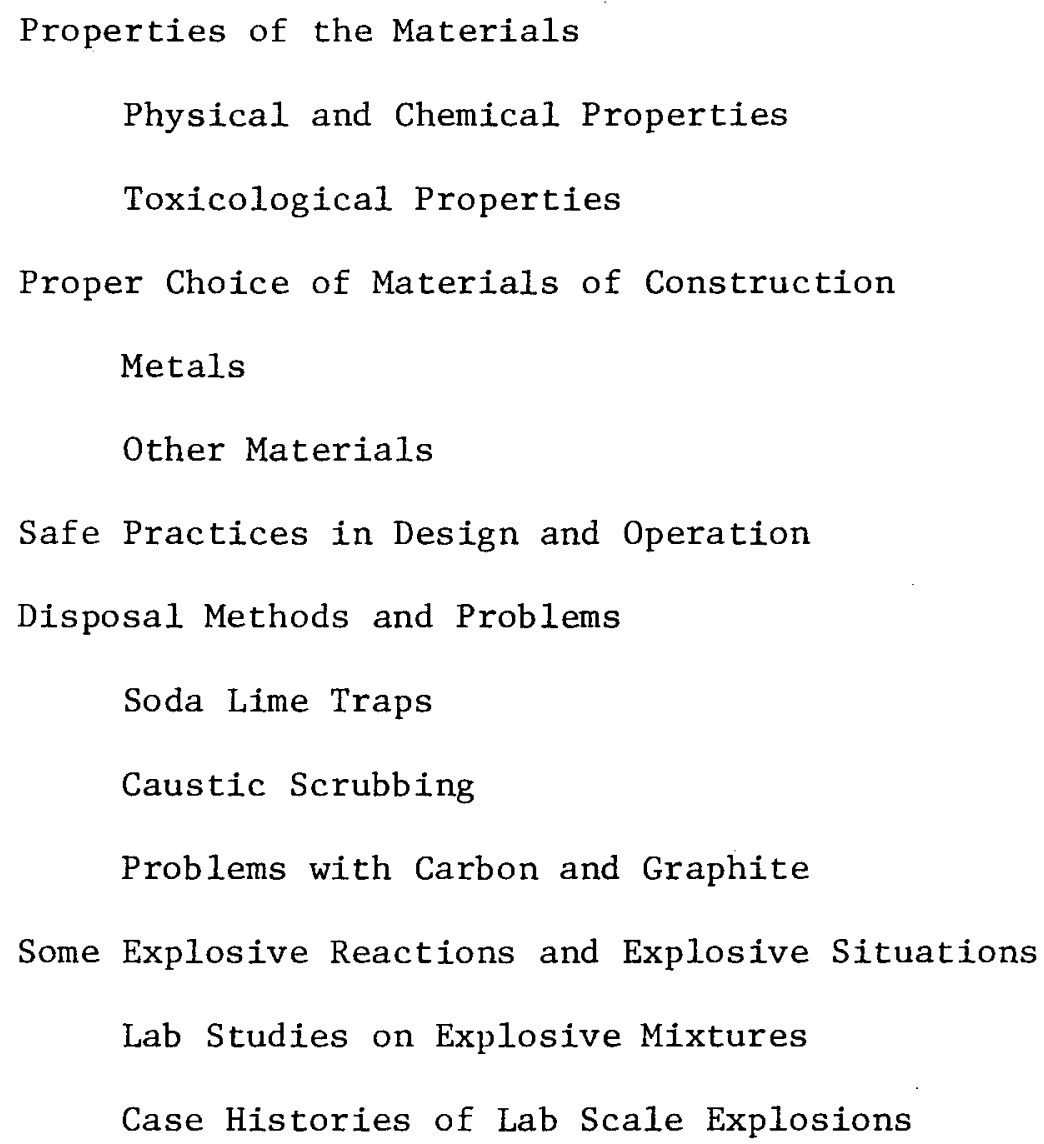

\begin{abstract}
SUMMARY
This paper reviews many considerations in the safe handling of fluorine and the chlorine fluorides. The physical, chemical, and toxicological properties of the materials are reviewed. Proper choice of materials of construction and materials in contact with the active gases are considered. The survey includes safe practices in design and operation of experiments and processes. Soda lime traps and caustic scrubbing are reviewed for fluorine disposal methods. Finally some explosive reactions and explosive situations are discussed.
\end{abstract}

\title{
PROPERTIES OF THE MATERIALS
}

Physical and Chemical Properties

Some of the physical properties of fluorine are listed in Figure 2, with comparable values for nitrogen and oxygen for reference. Fluorine is a 
Figure 2

SOME PHYSICAL PROPERTIES OF FLUORINE COMPARED

TO NITROGEN AND OXYGEN

\begin{tabular}{|c|c|c|c|}
\hline & $\begin{array}{l}\text { Nitrogen } \\
\mathrm{N}_{2} \\
\end{array}$ & $\begin{array}{l}\text { F1uorine } \\
\mathrm{F}_{2} \\
\end{array}$ & $\begin{array}{c}\text { Oxygen } \\
\mathrm{O}_{2} \\
\end{array}$ \\
\hline Melting point, ${ }^{\circ} \mathrm{C}$ & -209.86 & -219.62 & -218.4 \\
\hline Boiling point, ${ }^{\circ} \mathrm{C}$ & -195.8 & -188.14 & -183.0 \\
\hline $\begin{array}{l}\text { Vapor pressure at liquid } \mathrm{N}_{2} \\
\text { temperature, atm }\end{array}$ & 1.00 & 0.38 & 0.21 \\
\hline $\begin{array}{l}\text { Vapor pressure at liquid } \mathrm{O}_{2} \\
\text { temperature, atm }\end{array}$ & 3.61 & 1.66 & 1.00 \\
\hline
\end{tabular}

gas at ordinary temperatures, with a boiling point which lies between that of oxygen and nitrogen, and it may be condensed to a liquid by either liquid oxygen or liquid nitrogen. Note that fluorine will begin to condense in a liquid nitrogen-cooled cold trap when the fluorine pressure approaches about $0.4 \mathrm{~atm}$, whereas it can be raised to about 1.6 atm in a liquid oxygen-cooled trap before condensation commences. The hazard to be avoided is inadvertent collection of liquid fluorine.

Some of the physical properties of the chlorine fluorides are listed in Figure 3. These compounds are less volatile than fluorine. Chlorine trifluoride is usually obtained as a liquified gas with a vapor pressure of about $11 \mathrm{psig}$ at $25^{\circ} \mathrm{C}$.

Figure 3

SOME PROPERTIES OF CHLORINE FLUORIDES

\begin{tabular}{lcccc}
\hline & $\begin{array}{c}\text { Chlorine } \\
\text { Monofluoride } \\
\mathrm{C} 1 \mathrm{~F}\end{array}$ & $\begin{array}{c}\text { Chlorine } \\
\text { Trifluoride } \\
\mathrm{C} 1 \mathrm{~F}_{3}\end{array}$ & $\begin{array}{c}\text { Chlorine } \\
\text { Pentafluoride } \\
\mathrm{C} 1 \mathrm{~F}_{5}\end{array}$ \\
\cline { 2 - 3 } & -154. & -76.32 & -93 \\
Belting point, ${ }^{\circ} \mathrm{C}$ & -100.8 & +11.75 & -12.9 \\
\hline
\end{tabular}

Organic materials of any kind are usually extremely reactive with fluorine; and, depending on the quantity of materials involved, fires and explosions can result. Water can also react vigorously with fluorine with great evolution of heat; the reaction with chlorine trifluoride can be even more violent. Hydrolysis of the chlorine fluorides can 
produce products which are themselves explosive in nature, as shown in Figure 4. Finely divided materials are quite reactive because of the greater surface exposed for reaction. With most metals, fluorine forms a thin protective film which limits further reaction, but if the metals are finely divided, the heat of reaction cannot be dissipated quickly, and the reaction can become violent. Even finely divided ceramic materials can be ignited in fluorine.

\section{Toxicological Properties}

Fluorine can be detected by odor at a concentration below a tenth of a part per million as shown in Figure 5. The threshold limit value recommended by the American Conference of Governmental Industrial Hygienists (E1) is $1.0 \mathrm{ppm}$ based on a weighted average exposure for $8 \mathrm{hr} / \mathrm{day}, 40 \mathrm{hr} /$ week.

This value represents the concentration level where $1 \mathrm{t}$ is believed that almost all workers can be repeatedly exposed, day after day, without adverse effect. It is recognized that a few individuals may experience some discomfort at the threshold level, but these individuals represent a very small percentage of the work force. Exposure significantly above the threshold level can be permitted for shorter periods of time. The National Research Council recognizes two series of limits: the emergency tolerance limits (ETL's) and the emergency exposure limits (EEL's). The ETL's are guidelines for the brief occupational exposures which might be required of specific personnel who have the prior approval of a competent physician. The EEL's are designed to limit occupational exposures; exposures at these levels may involve some discomfort, but the effects are reversible - you will get over it. These levels are disaster control guidelines for a once-in-a-lifetime situation. The data which have been used to arrive at these levels (the ETL's and EEL's) have been reviewed by Ricca (E6) in a 1970 publication.

Higher concentrations become so irritable that one's first impulse is to leave the area. At concentrations of about $50 \mathrm{ppm}$, breathing is reported to be impossible without respiratory equipment (E7). Skin irritation

occurs at about $100 \mathrm{ppm}$. Figure 6 shows threshold limit values for other fluorine-containing compounds and a few other common materials are indicated for reference.

\section{MATERIALS OF CONSTRUCTION}

\section{Metals}

Proper choice of materials of construction is essential for the safe operation of any system or piece of equipment. The common metallic materials of construction (B4) for use with fluorine near room temperature or below about $250^{\circ} \mathrm{F}$ are iron, steel, Mone1, nickel, copper, brass, and aluminum. All these metals form thin, protective corrosion films, and of course some are more protective than others. Iron and steel are 


\section{HYDROLYSIS REACTIONS OF THE CHLORINE FLUORIDES}

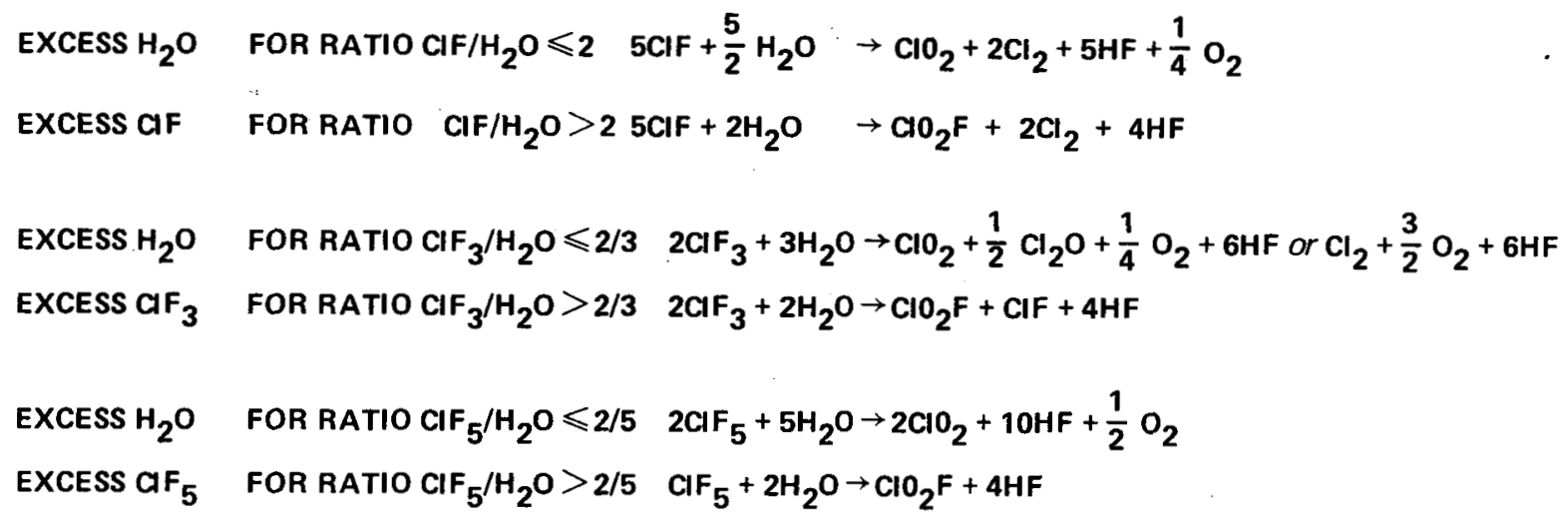




\section{FLUORINE CONCENTRATION EFFECTS}

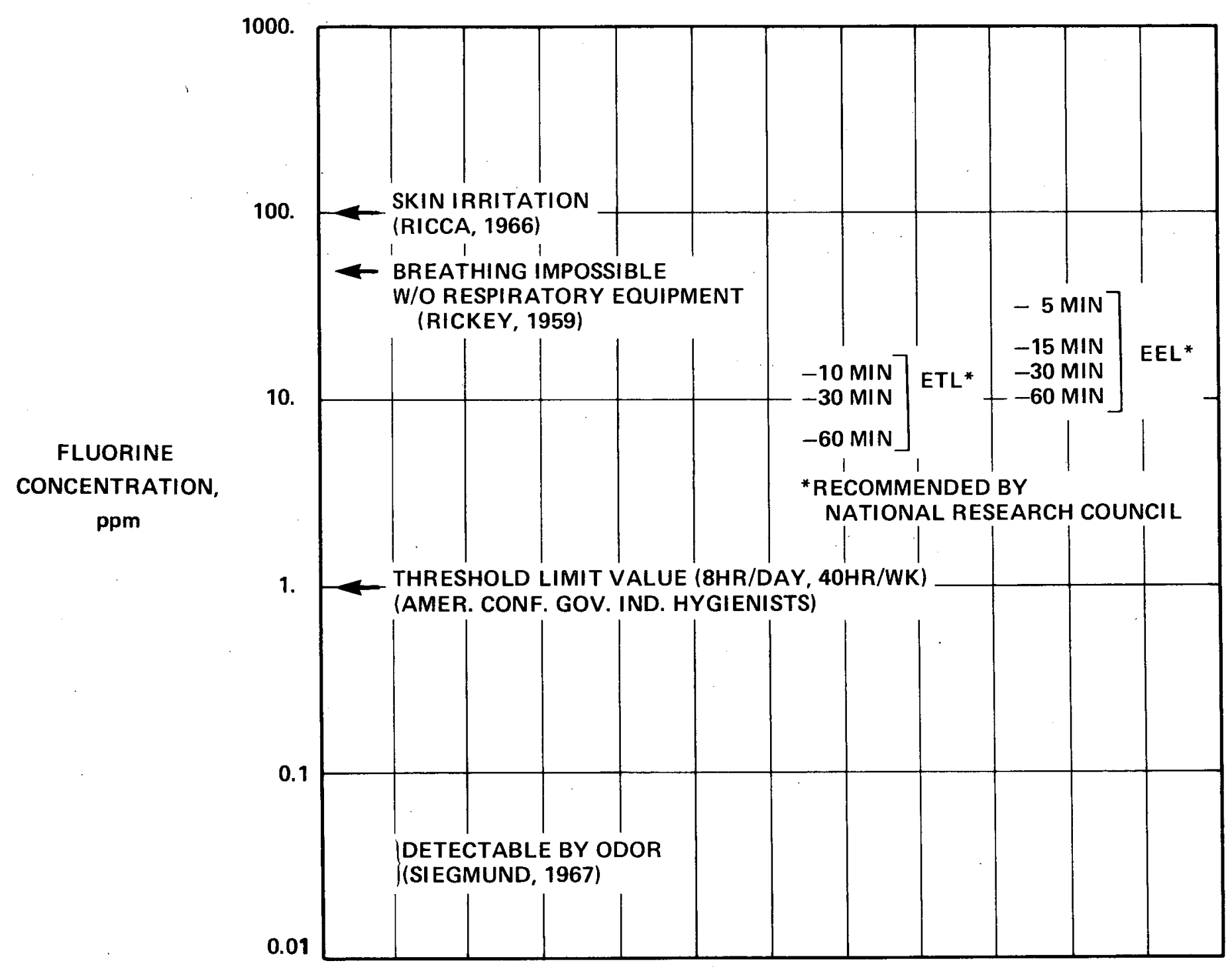

Figure 5 
THRESHOLD LIMIT VALUES

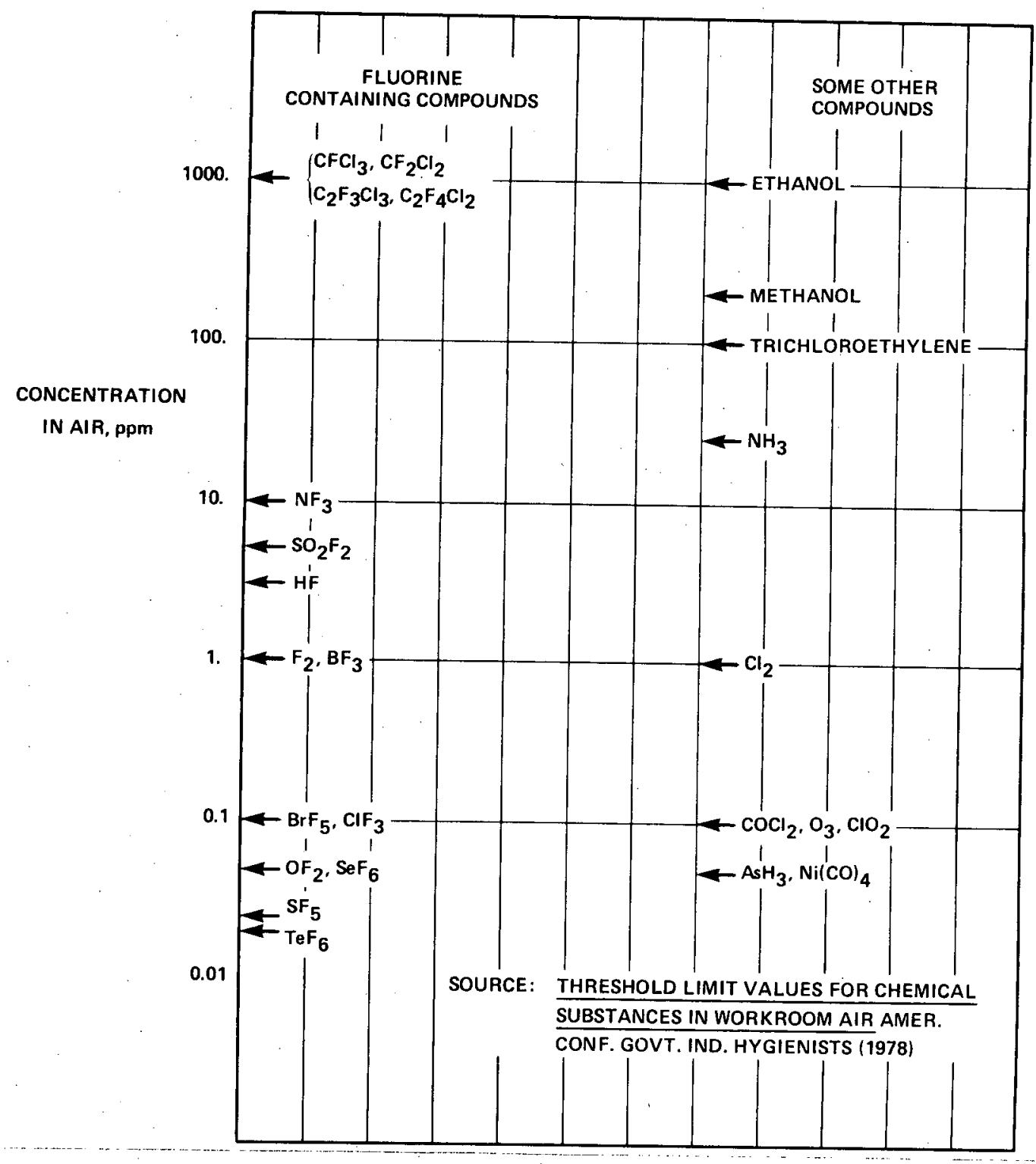

Figure 6 
the common commercial storage container materials; Monel and nickel are the best materials (C1) for systems, tubing, etc., and are definitely recommended for elevated-temperature operations. Copper tubing is useful in many applications, especially near room temperature; however, as the temperature increases, it becomes progressively more reactive than nickel and Monel.

The next group of Figures will show in more detail some of the factors which should be considered in choosing metallic materials of construction and materials compatible (Figure 7) in various fluorinating atmospheres. Fluorine (Figure 8) is a very strongly oxidizing gas. It attacks all metals, and the extent of reaction depends upon the nature of the fluoride which is formed. This fluoride may be a volatile vapor, a loose powder, or a tightly bound continuous film, which may itself be coated with a layer of sorbed fluorine atoms. The attack of fluorine on oxides and hydroxides is generally slower and is dependent upon the kinetics of molecular oxygen displacement.

Chlorine trifluoride (Figure 9) is also strongly oxidizing and is readily chemisorbed on surfaces. If there is an excess of $\mathrm{C}_{1} \mathrm{~F}_{3}$, it may act like fluorine in attacking metals, but if there is a deficiency it may be disruptive to a protective film, especially a thin film. Its attack upon oxides, oxyfluorides, and hydroxides may be more rapid than fluorine's since the $\mathrm{ClF}_{3}$ reactions do not depend upon molecular oxygen displacement.

Hydrogen fluoride (Figure 10) is a nonoxidizing, readily chemisorbed, solvating, polymeric vapor. It reacts with metals above hydrogen in the electromotive series, and hydrogen is a reaction product which can destroy metal protective films. The attack of $\mathrm{HF}$ on oxides and hydroxides may be rapid, and these reactions are also not dependent upon molecular oxygen formation.

In summary, (Figure 11) fluorine produces the most stable metal fluoride films. Chlorine trifluoride can clean or dry a surface more readily than fluorine. The HF level should generally be limited to "as low as practical."

Other factors in selecting metals for construction are summarized in Figure 12. Only one stable metal fluoride should be formed. For example, the iron fluoride film is less stable than the nickel fluoride and can be dusted off at elevated temperatures, in part because ferric iron is adjacent to the gas surface while ferrous iron may be in the film in the vicinity of the metal interface. Volume expansion on conversion to the fluoride should not be excessive; and the metal fluoride should be stable to hydration and hydrolysis if the system is to be repeatedly opened and closed. The metal fluoride film must be continuous and adherent over the temperature range of use; and the metallurgical and mechanical properties must be compatible with service conditions.

In alloy selection (Figure 13) the diffusing element in the alloy must form only one stable, nonvolatile fluoride. With Monel and Inconel the 


\section{FLUORINATING ATMOSPHERES}

- SIMILAR IN MANY WAYS, DIFFERENT FLUORINATING AGENTS DO EXHIBIT DIFFERENCES IN ATTACK UPON MATERIALS



Figure 7 


\section{FLUORINE}

- STRONGLY OXIDIZING GAS

- STRONGLY ATTACKS ALL METALS INITIALLY

- EXTENT OF REACTION DEPENDS UPON NATURE OF FLUORIDE FORMED

VOLATILE VAPOR

LOOSE POWDER

TIGHTLY BOUND, CONTINUOUS FILM

- TIGHTLY BOUND FLUORIDE FILM MAY BE COATED WITH LAYER OF FLUORINE ATOMS

- ATTACK UPON OXIDES AND HYDROXIDES DEPENDENT UPON THE KINETICS OF MOLECULAR OXYGEN DISPLACEMENT

$-2 \mathrm{NiO}+2 \mathrm{~F}_{2} \longrightarrow 2 \mathrm{NiF}_{2}+\mathrm{O}_{2}$

$-\mathrm{Ni}(\mathrm{OH})_{2}+2 \mathrm{~F}_{2} \rightarrow \mathrm{NiF}_{2}+\mathrm{O}_{2}+2 \mathrm{HF}$

Figure 8 


\section{CHLORINE TRIFLUORIDE}

- STRONGLY OXIDIZING, READILY CHEMISORBED VAPOR

- MAY ACT LIKE FLUORINE IN ATTACKING METALS

(IN EXCESS)

$-\mathrm{Ni}+\mathrm{ClF}_{3} \rightarrow \mathrm{NiF}_{2}+\mathrm{ClF}$

$-2 \mathrm{Al}+3 \mathrm{ClF}_{3} \longrightarrow 2 \mathrm{AlF}_{3}+3 \mathrm{ClF}$

- CHEMISORBED, $\mathrm{ClF}_{3}+\mathrm{F}^{-} \longrightarrow \mathrm{ClF}_{4}^{-}$, ON SURFACE

- MAY BE DISRUPTIVE OF PROTECTIVE FILM (IF DEFICIENCY)

$-4 \mathrm{Ni}+2 \mathrm{ClF}_{3} \longrightarrow 3 \mathrm{NiF}_{2}+\mathrm{NiCl}_{2}$

$-4 \mathrm{Al}+3 \mathrm{ClF}_{3} \longrightarrow 3 \mathrm{AlF}_{3}+\mathrm{AlCl}_{3}$

- ATTACK UPON OXIDES, OXYFLUORIDES, AND

HYDROXIDES DOES NOT DEPEND UPON MOLECULAR OXYGEN DISPLACEMENT

$-2 \mathrm{NiO}+2 \mathrm{ClF}_{3} \rightarrow \mathrm{NiF}_{2}+\mathrm{ClO}_{2} \mathrm{~F}+\mathrm{ClF}$

$-\mathrm{UO}_{2} \mathrm{~F}_{2}+2 \mathrm{ClF}_{3} \rightarrow \mathrm{UF}_{6}+\mathrm{ClO}_{2} \mathrm{~F}+\mathrm{ClF}$

$-\mathrm{Ni}(\mathrm{OH})_{2}+2 \mathrm{ClF}_{3} \longrightarrow \mathrm{NiF}_{2}+\mathrm{ClO}_{2} \mathrm{~F}+\mathrm{ClF}+2 \mathrm{HF}$

Figure 9

\section{HYDROGEN FLUORIDE}

- NONOXIDIZING, READILY CHEMISORBED, SOLVATING, POLYMERIC VAPOR

- REACTS WITH METALS ABOVE HYDROGEN IN ELECTROMOTIVE SERIES

$-\mathrm{Ni}+2 \mathrm{HF} \longrightarrow \mathrm{NiF}_{2}+\mathrm{H}_{2}$

$-2 \mathrm{Al}+6 \mathrm{HF} \rightarrow 2 \mathrm{AlF}_{3}+3 \mathrm{H}_{2}$

- CHEMISORBED, $\mathrm{HF}+\mathrm{F}^{-} \longrightarrow \mathrm{FHF}^{-}$

- SOLVATED, NaF $+2 \mathrm{HF} \rightarrow \mathrm{NaF} \cdot 2 \mathrm{HF}$

- PROTECTIVE METAL FLUORIDE FILMS DESTROYED BY $\mathrm{H}_{2}$ FORMATION

- ATTACK UPON OXIDES AND HYDROXIDES IS NOT DEPENDENT UPON MOLECULAR OXYGEN FORMATION

$-\mathrm{NiO}+2 \mathrm{HF} \rightarrow \mathrm{NiF}_{2}+\mathrm{H}_{2} \mathrm{O}$

$-\mathrm{AlO}(\mathrm{OH})+\mathrm{HF} \longrightarrow \mathrm{AlOF}+\mathrm{H}_{2} \mathrm{O}$

- PRESENCE OF HF IS A COMPLICATING FACTOR IN FLUORINATING SYSTEMS 


\section{DEDUCTIONS}

- FLUORINE RESULTS IN THE PRODUCTION OF THE MOST STABLE METAL FLUORIDE FILMS

$\therefore F_{2}$ SHOULD BE THE STABILIZING GAS OF CHOICE

- CHLORINE TRIFLUORIDE WILL CLEAN UP A SURFACE MORE READILY THAN FLUORINE

$\therefore \mathrm{CIF}_{3}$ IS THE LOGICAL GAS TO CONDITION OR TO DRY A SURFACE

- HYDROGEN FLUORIDE MAY DESTROY A METAL FLUORIDE FILM (IF PARTIAL. PRESSURE IS HIGH ENOUGH TO SOLVATE THE METAL FLUORIDE OR TO DIFFUSE THROUGH IT)

$\therefore$ HF CONCENTRATION SHOULD BE LIMITED TO "LOW AS PRACTICAL LEVEL"

Figure 11 


\section{FACTORS IN SELECTING METALS}

- ONLY ONE STABLE METAL FLUORIDE WHICH MUST ALSO BE NONVOLATILE IS FORMED

- VOLUME EXPANSION ON CONVERSION TO FLUORIDE MUST NOT BE EXCESSIVE

- USUALLY LIMITS CHOICE TO METAL FORMING A DIVALENT OR TRIVALENT FLUORIDE FILM $\mathrm{NiF}_{2}, \mathrm{AlF}_{3}, \mathrm{MgF}_{2}$

- METAL FLUORIDE MUST BE STABLE TO HYDRATION AND HYDROLYSIS IF SYSTEM IS TO BE REPEATEDLY OPENED AND CLOSED

- METAL FLUORIDE FILM MUST BE CONTINUOUS AND REMAIN TIGHTLY ADHERENT OVER TEMPERATURE RANGE OF USE

- METALLURGICAL AND MECHANICAL PROPERTIES MUST BE COMPATIBLE WITH SERVICE CONDITIONS 


\section{ALLOY SELECTION - 1}

- DIFFUSING ELEMENT IN ALLOY MUST FORM ONLY ONE STABLE, NONVOLATILE FLUORIDE

- MONEL, INCONEL - NiF 2 FILM

- ALLOY SHOULd be SINGLE PHASE

- IN MULTIPHASE ALLOYS ONE PHASE IS ATTACKED VERY RAPIDLY

- FREQUENTLY EXHIBIT INTERGRANULAR CORROSION AND/OR STRESS CORROSION CRACKING

- ONE PHASE MAY BE LEACHED OUT COMPLETELY

- ALLOYS BECOME INCOMPATIBLE AT LOWER TEMPERATURES THAN THE RESISTANT PURE ELEMENT

- INTERMETALLIC COMPOUNDS MAY CORRODE MUCH MORE RAPIDLY THAN THE PURE COMPONENT ELEMENTS

- IRON - ALUMINUM, ZINC - IRON, ALUMINUM - ZINC 
fluoride film is $\mathrm{NiF}_{2}$. The alloy should be single phase since in multiphase alloys, one phase is attacked more rapidly, and it frequently exhibits intergranular corrosion and/or stress corrosion cracking. One phase may be leached out completely. Alloys become incompatible at lower temperatures than the resistant pure element. Intermetallic compounds may corrode much more rapidly than the pure component.

For less resistant materials (Figure 14), one can plate the surface with a resistant metal. Electroplated nickel is usually best but electroless nickel plate is also used. Flame spraying and plasma spraying present porosity problems. Covering with a resistant organic film may involve a solubility problem or an adhesive problem. Figure 15 illustrates failures caused by a degree of porosity of a flame sprayed coating; and Figure 16 shows intrusion of reaction products at the interface of the metal and the coating.

The corrosion rates of several metals are summarized in Figure 17. Nickel is the best, with the worst being stee1, which has variable and severe corrosion rates at elevated temperatures. Some of the problem metals which form volatile fluorides are shown in Figure 18, and Figure 19 shows several cases of nonprotective fluoride films. $\mathrm{AgF}_{2}$ is hygroscopic and not adherent. Tin and lead fluorides are nonprotective; soft solders should be avoided. Some metals (Figure 20), for example, gold, platinum, and chromium, form stable films at ambient temperatures but fail at high temperatures. For joining metals used in fluorine service, welding is the best for steel, nickel, or Mone1. In some applications silver solder is also satisfactory, but soft solder should be avoided.

Other Materials

Plastic materials suitable for use in fluorine atmospheres are shown in Figure 21. These materials are used for gaskets, valve seats, etc. When they are used as gaskets, especially at elevated temperatures, it is desirable to confine the material in a tongue-and-groove arrangement to minimize the area exposed to fluorine and also to minimize their tendency to "cold flow." Gasket materials, in addition to the fluoroplastic materials, may be aluminum or soft, annealed copper; all should be cleaned and degreased, preferably with solvent TF (1,1,2-trichlorotrifluoroethane). If a lubricant is needed for threaded connections, a Teflon dispersion (applied from an aqueous carrier and then dried) or very thin Teflon tape have been successfully used.

Polyvinyl chloride is a good material for protective clothing (gloves, etc) although neoprene is frequently used. Even these materials, however, will ignite in high concentrations of fluorine. There is no known material which affords complete protection under all conditions. 


\section{PROTECTION FOR LESS RESISTANT MATERIALS}

- Plating WITH RESISTANT METAL

- USUALLY ELECTROPLATED NICKEL

- ELECTROLESS NICKEL PLATE FOR SPECIALTY ITEMS

- HEAT TREATING IMPROVES ADHERENCE, INCREASES CORROSION

- HIGHLY STRESSED AND BRITTLE - RAPID FAILURE

- COATING WITH RESISTANT METAL

- FLAME SPRAYING - POROSITY PROBLEM

- PLASMA SPRAYING - POROSITY PROBLEM

- HOT DIPPING - HIGHLY REACTIVE INTERMETALLICS FORMED

- CLADDING BY EXPLOSIVE BONDING AND ROLLING HOLIDAYS AND UNBONDED AREAS

- COVERING WITH RESISTANT ORGANIC FILM

- SOLUBILITY PROBLEM

- ADHESIVE PROBLEM

Figure 14 




EFFECT OF POROSITY IN NICKEL ALUMINIDE FLAME SPRAYED COATINGS ON STEEL SUBSTRATES WHEN EXPOSED TO FLUORINATING MEDIA. 


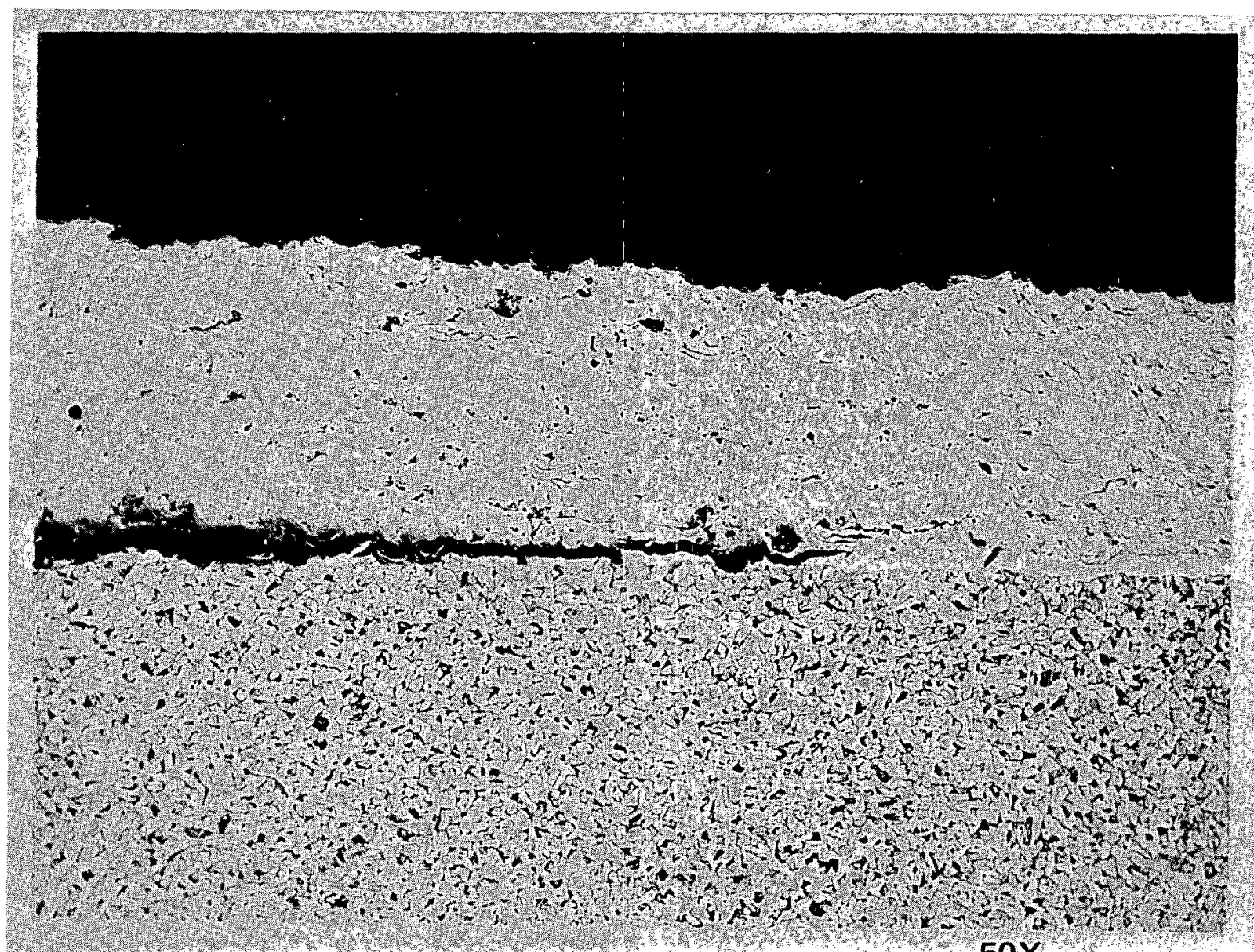

\section{$50 \times$}

\section{PLASMA JET NICKEL COATING LIFTED FROM STEEL SUBSTRATE BY INTRUSION OF CORROSION PRODUCTS AT INTERFACE}

Figure 16 


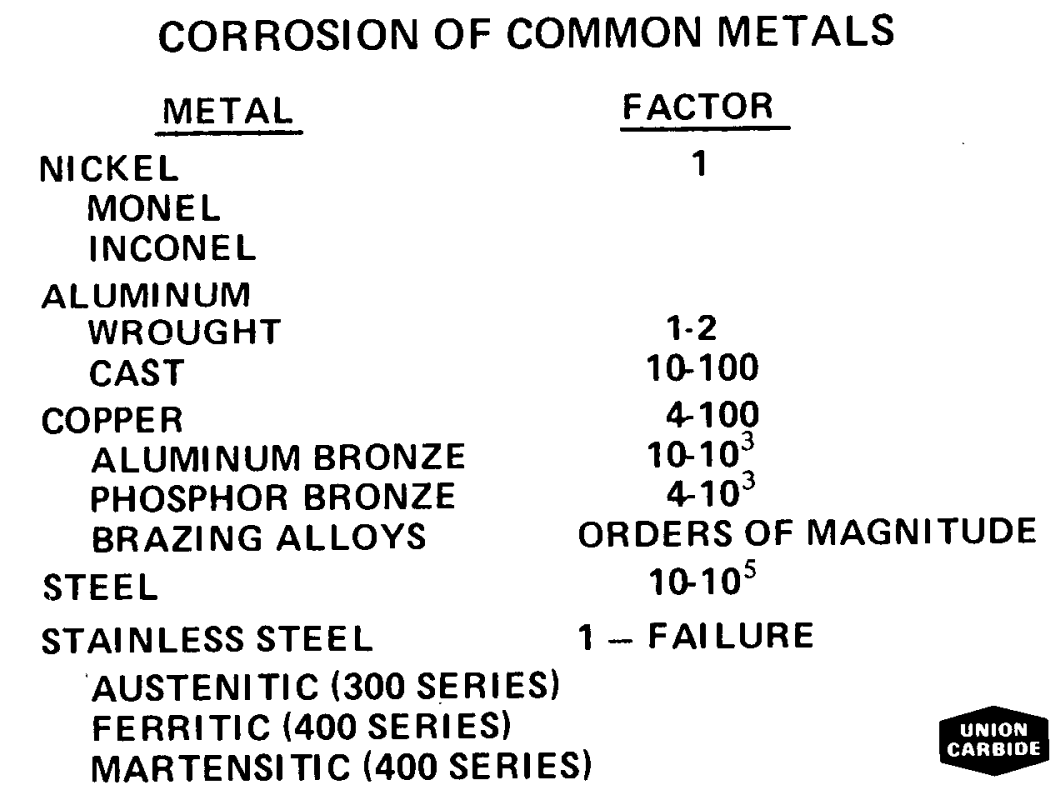

Figure 17 


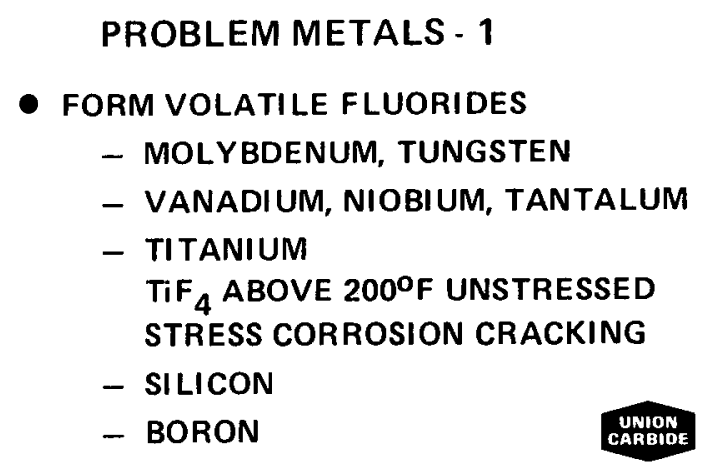

Figure 18

PROBLEM METALS - 2

- FLUORIDE FILMS FORMED ARE UNPROTECTIVE

- SILVER

AgF $_{2}$, HYGROSCOPIC, FORMS WITH $\mathrm{F}_{2}, \mathrm{CIF}_{3}$ - NOT ADHERENT AgF FORMED WITH UF ${ }_{6}$ ALSO UNPROTECTIVE

- TIN

$\mathrm{SnF}_{2}$, UNPROTECTIVE, FORMED WI TH UF 6

$\mathrm{SnF}_{4}$, UNPROTECTIVE, FORMED WITH $\mathrm{ClF}_{3}, \mathrm{~F}_{2}$

$\mathrm{SnF}_{2}$ HYDRATES, $\mathrm{SnF}_{4}$ HYDROLYZES

- LEAD

$\mathrm{PbF}_{2}$ UNPROTECTIVE BUT NOT VOLATILE-FORMED AT ROOM

TEMPERATURE

$\mathrm{PbF}_{4}$ MODEST VOLATILITY, EASILY HYDROLYZED, NO

PROTECTION

- BISMUTH, CADIUM, INDIUM

- SOFT SOLDERS

- GOLD BASED BRAZE ALLOYS 
PROBLEM METALS - 3

- STABLE BEHAVIOR AT AMBIENT temPERATURE

- FAILURE AT HIGHER TEMPERATURES

- GOLD MORE RESISTANT TO UF 6 THAN TO $F_{2}$ - USEFUL TO AT LEAST $150^{\circ} \mathrm{F}$

- PLATINUM, PALLADIUM, RHODIUM DIVALENT FLUORIDES PROTECTIVE-FAIL WHEN HIGHER VALENCE FLUORIDES FORM

- CHROMIUM DIVALENT FLUORIDE IS PROTECTIVE-SOME UTILITY TO ABOUT $250^{\circ} \mathrm{F}, \mathrm{I.E} ., 200^{\circ}<\mathrm{T}<300^{\circ} \mathrm{F}$

Figure 20 
FLUOROPOLYMERS STABLE TO FLUORINE

\begin{tabular}{|c|c|c|c|}
\hline IDEAL STRUCTURAL FORMULA & TRADE NAME & MANUFACTURER & APPLICATIONS \\
\hline$\left(-\mathrm{CF}_{2}-\mathrm{CF}_{2}{ }^{-1} \mathrm{x}\right.$ & $\begin{array}{l}\text { TEFLON TFE } \\
\text { HALON TFE } \\
\text { TETRAN } \\
\text { FLUON }\end{array}$ & $\begin{array}{l}\text { DUPONT COMPANY } \\
\text { ALLIED CHEMICAL CO. } \\
\text { PENNWALT COMPANY } \\
\text { ICI }\end{array}$ & USABLE TO $450^{\circ} \mathrm{F}$ IN CONFINED GASKETS. \\
\hline$\left(-\mathrm{CH}_{2}-\mathrm{CF}_{2}-\mathrm{CF}_{2}-\left.\right|_{\mathrm{CF}_{3}} ^{\mathrm{CF}-)_{\mathrm{X}}^{*}}\right.$ & TEFLON FEP & DUPONT COMPANY & $\begin{array}{l}\text { USABLE TO } 350^{\circ} \mathrm{F} \text { IN CONFINED GASKETS; } \\
\text { LESS “COLD FLOW" BELOW } 200^{\circ} \mathrm{F} \text { THAN } \\
\text { TFE: TRANSPARENT TO UV AND VISIBLE } \\
\text { LIGHT. }\end{array}$ \\
\hline 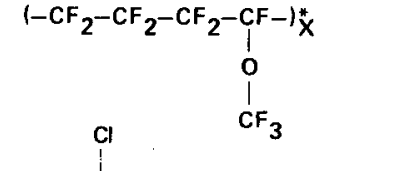 & TEFLON PFA & DUPONT COMPANY & USABLE TO $325^{\circ} \mathrm{F}$ \\
\hline${ }^{\left(\mathrm{CF}_{2}\right.}{ }_{\mathrm{F}}^{-\mathrm{C}-)^{-} \mathrm{x}}$ & $\begin{array}{l}\text { KELF } \\
\text { HALON CTFE }\end{array}$ & $\begin{array}{l}\text { 3M COMPANY } \\
\text { ALLIED CHEM. CO. }\end{array}$ & $\begin{array}{l}\text { USABLE TO } 250^{\circ} \text { F IN CONFINED GASKETS, } \\
\text { BUT SUBJECT TO CRYSTALLIZATION. }\end{array}$ \\
\hline$\underset{\mathrm{CF}_{3}}{\left.\mathrm{CF}_{2}-\underset{\mid}{\mathrm{CF}}-\mathrm{CH}_{2}-\mathrm{CF}_{2}-\right)_{\mathrm{X}}^{*}}$ & $\begin{array}{l}\text { VITON A } \\
\text { FLUOREL }\end{array}$ & $\begin{array}{l}\text { DUPONT COMPANY } \\
\text { 3M COMPANY }\end{array}$ & $\begin{array}{l}\text { FLUOROELASTOMERS WHICH MAY BE USEFUL } \\
\text { IN MILD APPLICATIONS. }\end{array}$ \\
\hline
\end{tabular}

Figure 21 
SAFE PRACTICES IN DESIGN AND OPERATION

We have talked about some of the physical and chemical properties and the toxicological properties of fluorine and the chlorine fluorides, as well as choices to be made in materials of construction; let us now consider some safe practices in design and operations of systems or equipment. The next Figure (Figure 22) illustrates in a general way several features of a typical fluorination system. We have a source of fluorine or fluorinating agent, a source of dry air or dry nitrogen for purging, backfilling, etc., a reactor of some design to conduct an experiment or to carry out some reaction or process. All components of this system will be fabricated from materials which are compatible with the fluorinating agents to be employed. Finally there is a disposal system of some kind which will be discussed in more detail at a later time.

The first common sense safety consideration is to avoid unnecessarily large quantities of these fluorinating materials in the immediate work area and to avoid unnecessarily high pressures of fluorine. Use whatever is necessary to accomplish the task, but avoid excess.

After assembly and fabrication of the equipment and before the first contact with fluorine, the equipment must be clean and free of hydrocarbon oils, grease, moisture, etc. This could well require careful degreasing of the components using some degreasing agent such as solvent TF (1,1,2-trichlorotrifluoroethane) before assembly. The equipment should be thoroughly leak tested after assembly. The initial contact of the equipment with fluorine is a time of potential hazard.

Safety glasses should be worn at all times (Figure 23) when handling fluorine, but one should wear these at all times in the laboratory anyhow. Recall that fluorine is easily detected by odor at a concentration of a few tenths of ppm, which level is well below the threshold limit value of $1 \mathrm{ppm}$. Any odor of fluorine in the work area should not be tolerated. Locate the source of the outleakage and correct the problem. Safety equipment such as gloves, protective clothing, and respirators should be nearby, perhaps just outside the work area; but one should not rely upon such equipment for the normal routine operation of the apparatus unless high pressure or liquid fluorine is involved. The facility should be carefully planned to anticipate trouble areas and situations and to avoid them to the extent possible. There is no known protective equipment which would be acceptable for high concentrations of fluorine. One cannot cover up sloppy work practices or improperly designed equipment or experiments with the use of protective equipment.

Care should always be exercised when introducing fluorine to a system, especially during the first contact. The surfaces have no protective fluoride film; and some reactive deposit, such as water, oil, grease, etc., might inadvertently be present. A recommended procedure would be to slowly add $0.1 \mathrm{~atm}$ fluorine and watch for hot spots or pressure rises or losses. Evacuate to the disposal trap immediately if any of these 
DWG. NO. K/G-79-1491

\section{TYPICAL FLUORINATION SYSTEM}

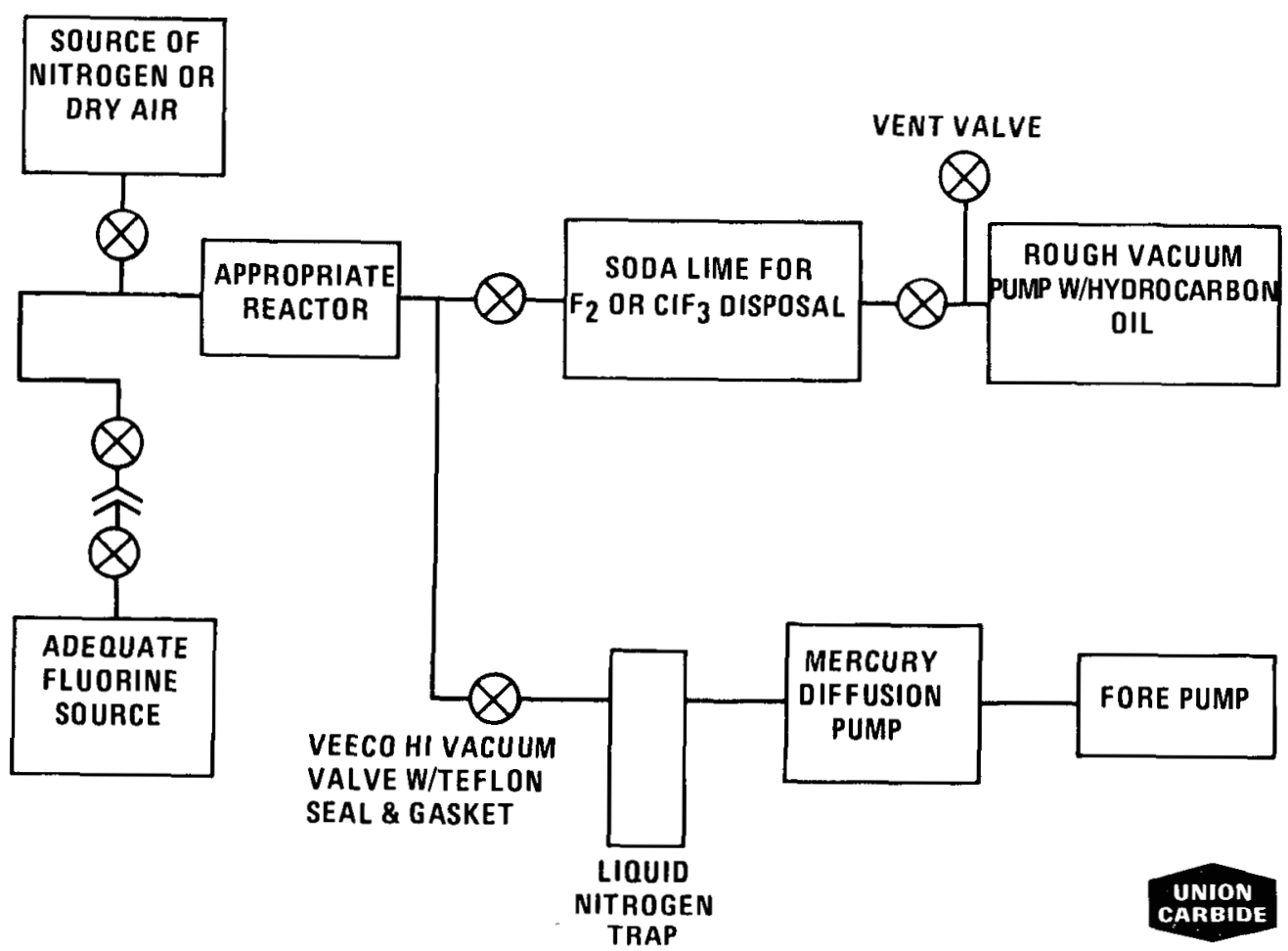

Figure 22 
DEUTERIUM FLUORINE FLAME REACTOR



Figure 23 
conditions appear. Look for and correct the source of any difficulty. It will usually be best to evacuate the first charge even if these symptoms don't appear and then raise the pressure incrementally and slowly to the operating pressure, stopping frequently to observe the pressure and temperature of the system. The system should be exposed to conditions somewhat above the maximum operating conditions of temperature and pressure before proceeding with the experiment. If small leaks develop or are detected by odor at anytime, the system should not be used further until these leaks are located and repaired. Aqueous ammonia and filter paper moistened with KI solution are useful in locating such leaks. All work of this nature should be performed in well ventilated work areas. If or when a system is to be opened to the atmosphere for any reason, be sure that the fluorine has been carefully evacuated; it is preferable to refill the system with dry air or nitrogen. When opening a fitting or flange, keep hands away from the connection. In the event that fluorine does flow out from the connection, seal it back immediately and evacuate the section again, more completely. All equipment containing fluorine or pipe lines containing fluorine should be clearly labeled as to their contents.

Another potential trouble area is a cold trap. It might, depending on the system which is being studied, contain materials which could explode when warmed to room temperature (see later discussion). Figure 24 illustrates a shielded cold trap for use when such materials might be encountered.

\section{DISPOSAL METHODS AND PROBLEMS}

Soda Lime Traps

A very useful fluorine disposal technique for laboratory or small scale situations is the use of the soda lime trap which was illustrated previous1y (Figure 22). Soda lime is a solid material and is a mixture of sodium and calcium oxides and hydroxides. It is commercially available in many sizes but the 4 to 8 mesh solid particles have been found to be quite useful in trap sizes which might vary from 3 to 5 in. in diameter and 3 to $5 \mathrm{ft}$ in length.

Soda lime picks up moisture rather quickly from the ambient atmosphere, which is undesirable. It is supplied in sealed containers, and in this condition it is relatively free of moisture. When traps are loaded or refilled, dry soda lime should be used or copious amounts of water will

be pumped off the soda lime. Such water can either be collected in a cold trap or it can enter the vacuum pump, where a liquid phase of water will build up beneath the vacuum pump oil. Water should be removed before using the trap; it can be removed from the vacuum pump by draining and replacing the pump oil. One should insure that the trap can be evacuated to about $10 \mu$ pressure before using it for fluorine disposal. 


\section{SHIELDED COLD TRAP}

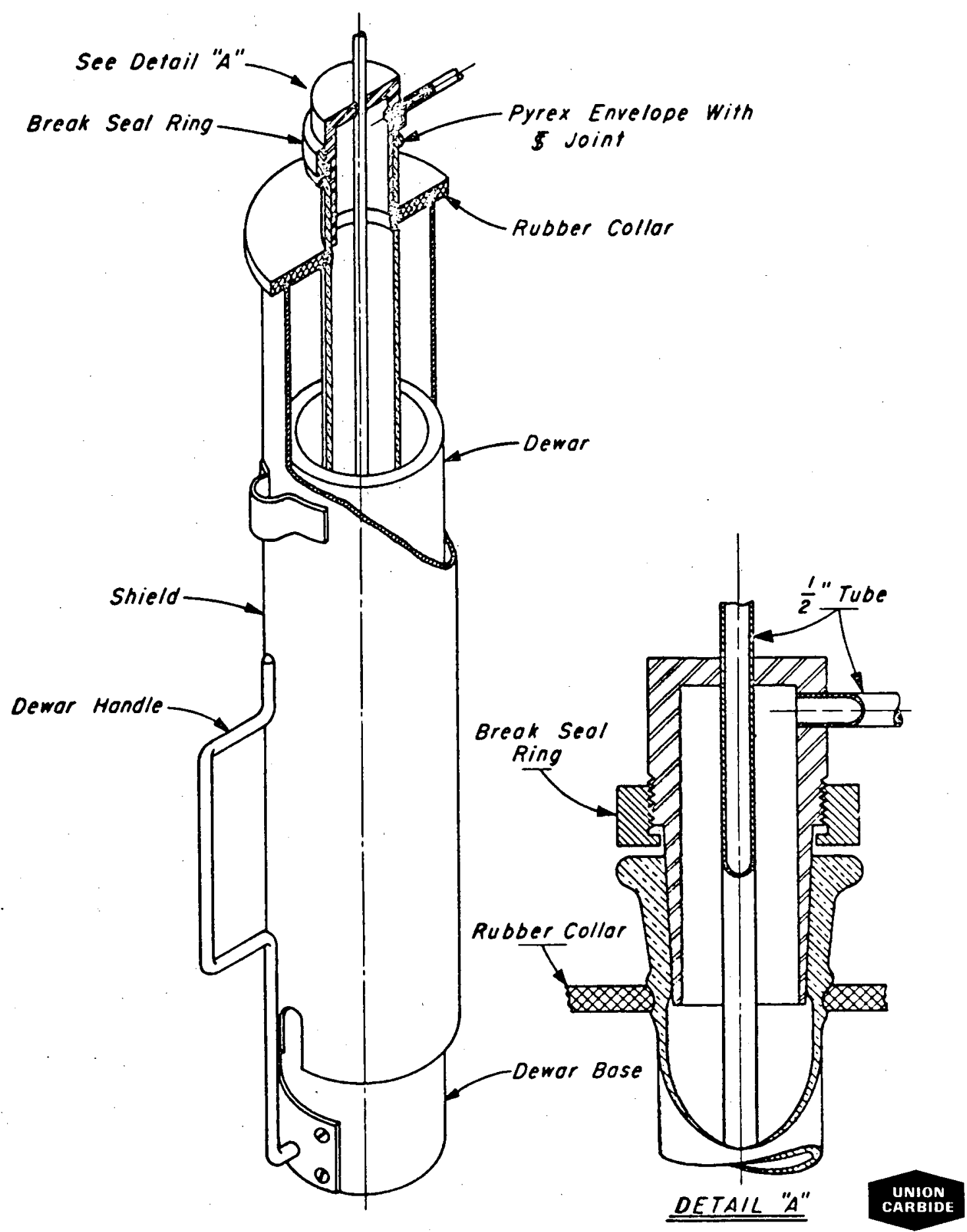

Figure 24 
One difficulty in use of a soda lime trap is to know when it is exhausted. If it is getting fairly heavy usage, one can feel a hot zone in the trap where the reaction is currently occurring. It is usually best to empty and recharge a trap when the hot zone indicates about $3 / 4$ of the trap material has been used. If only a small or trickle flow is entering the trap, the reaction zone might be more difficult to determine. However, under these conditions, near breakthrough, a small amount of fluorine will enter the vacuum pump harmlessly, and this trace flow will cause a gum in the vacuum pump which will cause it to stop. When this happens the soda lime trap is nearing the end of its life and should be changed out. The pump can be restored to operation by flushing with a suitable solvent and adding new vacuum pump oil.

Notice three essential valves in any soda lime trap installation: A valve at the entrance and exit to the trap and a vent valve on the vacuum pump. When the system is to be shut down, the soda lime trap should be filled to one atmosphere with dry air or dry nitrogen and both the entrance and exit valves closed. This will prevent the introduction of moisture from ambient air. The vent valve should be opened as soon as the vacuum pump is turned off to prevent the possible backflow of pump oil into the system. These three valves can save much grief.

Caustic Scrubbing

For disposal of large quantities of fluorine or chlorine fluorides, the $\mathrm{KOH}$ caustic scrubber (F1) has been used. The chemical reactions involved are shown in Figure 25. The essential parts of the system are shown in Figure 26. It consists of a recirculating solution, a concurrent scrubbing chamber, and a regeneration facility where lime can be added, batchwise, to precipitate the fluorine ions and regenerate the hydroxyl ions on a mole-for-mole basis. With $\mathrm{ClF}_{3}$, however, the fluoride can be regenerated but the chlorides and chlorates are not regenerated and require some blowdown for concentrations control.

Problems with Carbon and Graphite

The reaction of fluorine with carbon has been used for fluorine disposal, but after several violent reactions in the period 1943 to 1950 , we at the ORGDP do not use this reaction for that purpose. Some people have postulated the fluorine can react with powdered graphite at or near room temperature to produce a solid compound of fluorine and carbon which, after an induction period, is capable of undergoing a violent deterioration. This hypothesis is not fully consistent with many of the observations of Professor John Margrave and his work on the lower carbon fluorides. Physical adsorption of fluorine on the carbon surface may be a factor in the explosion mechanism. The violent reactions which we have witnessed have generally occurred when saturated or exhausted traps were being opened for removal of the contents. The initiating circumstances have involved, but were not limited to, striking the trap with a hammer, striking the carbon bed with the pointed end of a pry bar, and possibly 
CHEMICAL REACTIONS FOR THE KOH SCRUBBER

$$
\begin{array}{ll}
\text { SCRUBBING REACTION } & \mathrm{F}_{2}+2 \mathrm{KOH} \rightarrow 2 \mathrm{KF}+\mathrm{H}_{2} \mathrm{O}+\frac{1}{2} \mathrm{O}_{2} \\
& \mathrm{ClF}_{3}+4 \mathrm{KOH} \rightarrow 3 \mathrm{KF}+\frac{1}{3} \mathrm{KCl}+\frac{2}{3} \mathrm{KClO}_{3}+2 \mathrm{H}_{2} \mathrm{O} \\
\text { REGENERATION REACTION } & 2 \mathrm{KF}+\mathrm{Ca}(\mathrm{OH})_{2} \rightarrow \mathrm{CaF}_{2}+2 \mathrm{KOH}
\end{array}
$$

Figure 25 
SCHEMATIC DIAGRAM OF KOH SCRUBBER

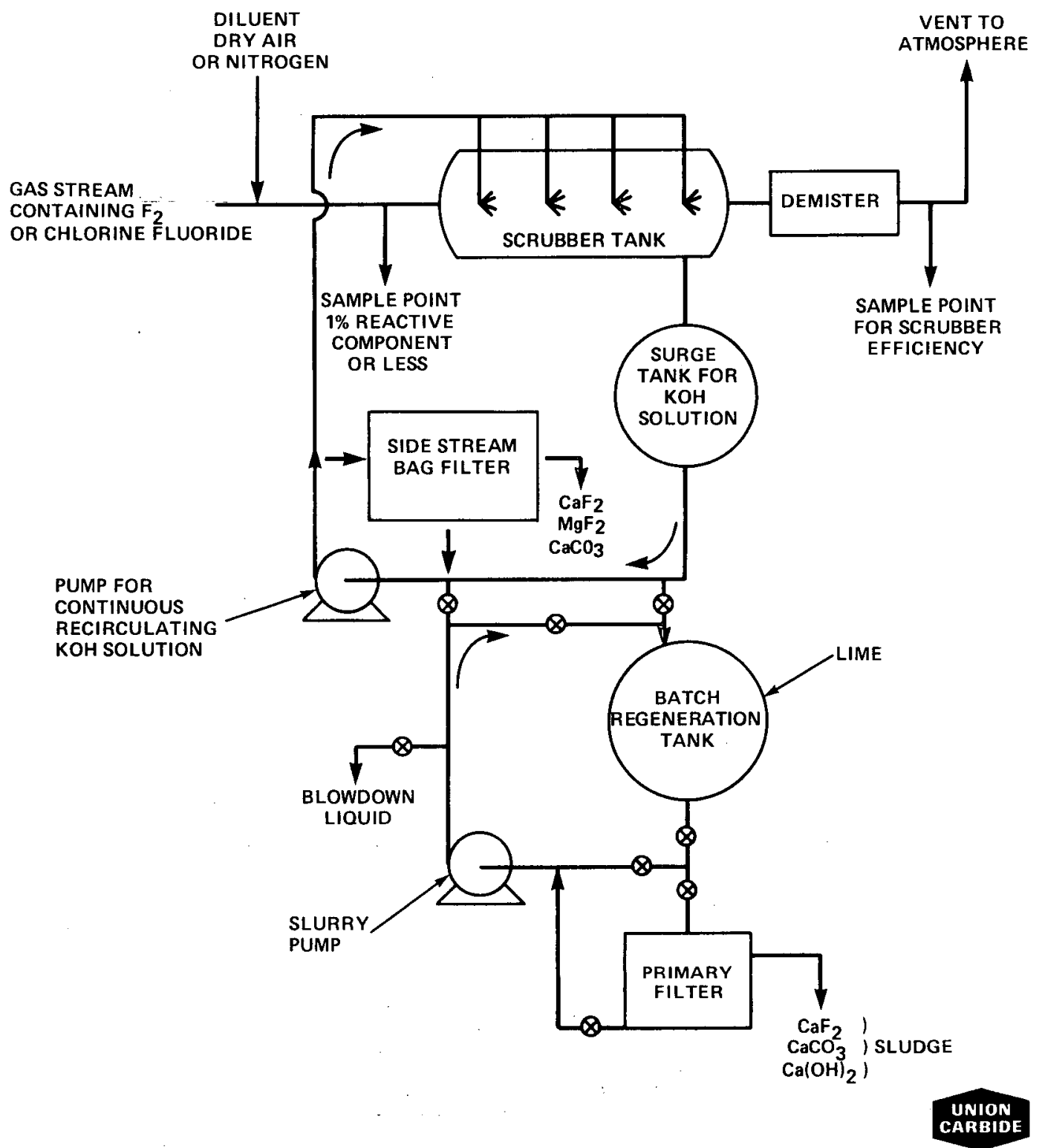

Figure 26 
the sudden exposure of the bed to wet air. A white coating was frequently noted on the surface of the carbon pellets.

More recently, NASA (B5) has investigated the reaction of fluorine with carbon further. They have confirmed the nature of the reaction with powdered graphite or crystallized carbon, but they report that the reaction with amorphous carbon and charcoal proceeds smoothly, even in very low concentrations of fluorine, to yield carbon tetrafluoride as the primary reaction product. This product is relatively nontoxic and, thus, provides a feasible method for venting large quantities of fluorine to the atmosphere. At the ORGDP, we still do not recommend this reaction for routine fluorine disposal. There are other very good materials which are more reliable.

\section{SOME EXPLOSIVE REACTIONS AND EXPLOSIVE SITUATIONS}

Lab Studies on Explosive Mixtures

The next series of Figures illustrate some work of Bernhardt, Hale, and Barber (D1) on unstable or explosive mixtures with fluorine and the effect of an inert diluent on these mixtures. Just as hydrogen and oxygen, or many hydrocarbons and air, can be mixed without reaction and exploded by a flame or spark, so also can fluorine and certain gaseous halocarbons. The situation with Freon 114 (Figure 27) will be presented to illustrate the effect. Binary mixtures of fluorine and Freon 114 have composition regions that are, to some degree, pressure dependent, where the mixture is stable or where the mixture can be exploded with a spark as shown in Figure 28. The ternary diagram for fluorine-Freon 114nitrogen mixtures is shown in Figure 29, where again there are explosive and non-explosive regions. These explosions can be quite sizable in magnitude, as shown in Figure 30, and depend on the initial composition of the mixture.

NASA (B5) has done a large amount of work with liquid fluorine. As we have long known in our experience with gaseous fluorine, NASA reports that the key to successful usage of this material is "scrupulous cleanliness." Traces of foreign material, ofl, hydrocarbons, or metal particles can lead to violent reactions or explosions. One of the worst materials with liquid fluorine is ice crystals. Liquid fluorine and ice will detonate, after an induction period. Since liquid fluorine is usually handled with liquid nitrogen or liquid oxygen, ice can be trapped out from the purge gases or from contact with ambient air. NASA recommends that purge gases to be used around liquid fluorine be dried to a dewpoint of less than $-90^{\circ} \mathrm{F}$ and contain less than $5 \mathrm{ppm}$ of methane or hydrocarbons. The NASA manual on fluorine is recommended for anyone using or contemplating usage of liquid fluorine. 
DWG. NO. G-69-32

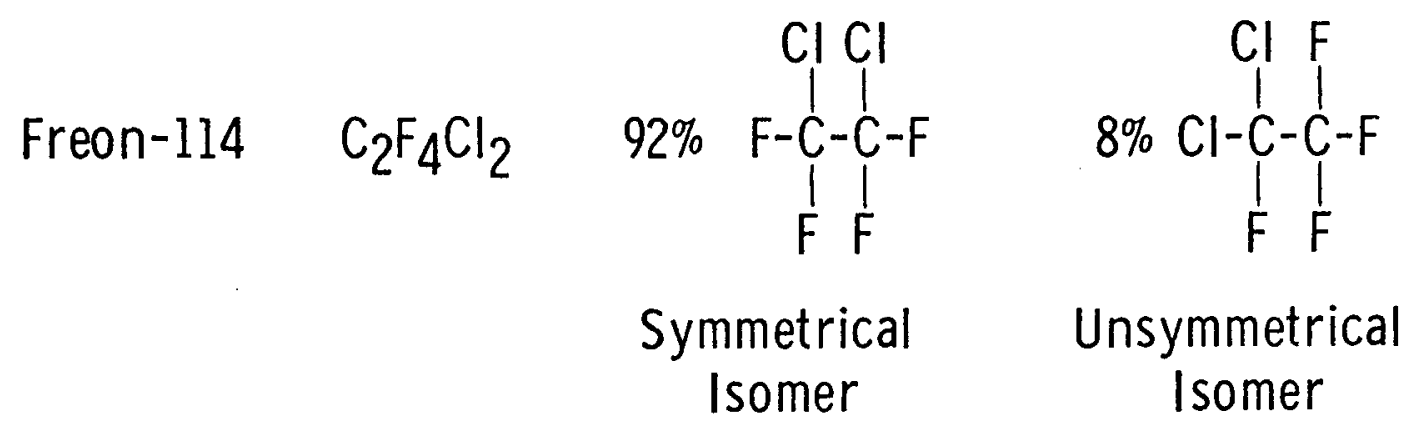

STRUCTURAL FORMULA FOR FREON 114

Figure 27 
DWG. NO. G-66-663

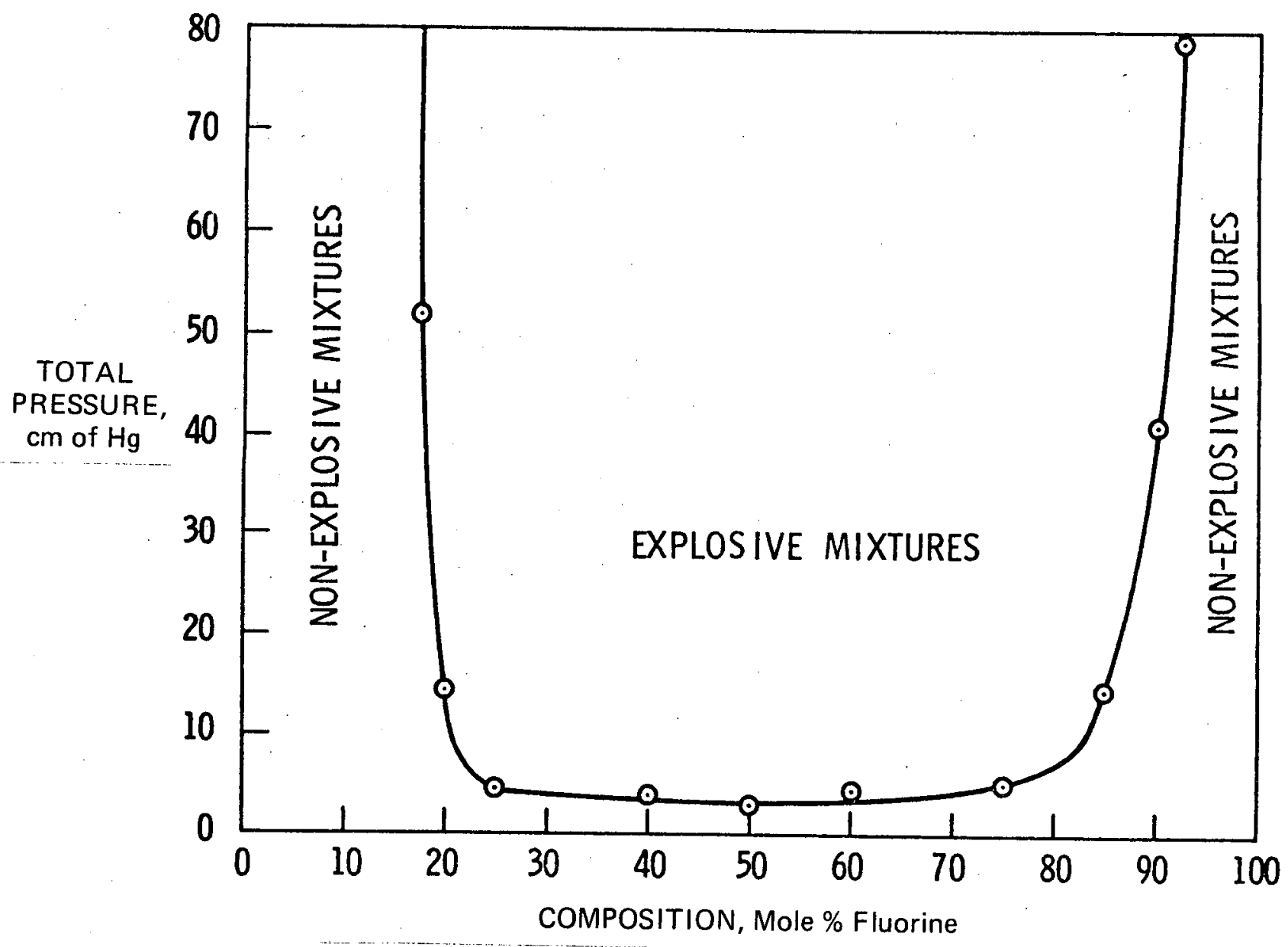

LOWER PRESSURE LIMITS FOR EXPLOSION IN MIXTURES

OF FREON- 114 WITH FLUORINE AT $25^{\circ} \mathrm{C}$

Figure 28 
DWG. NO. G-66-661

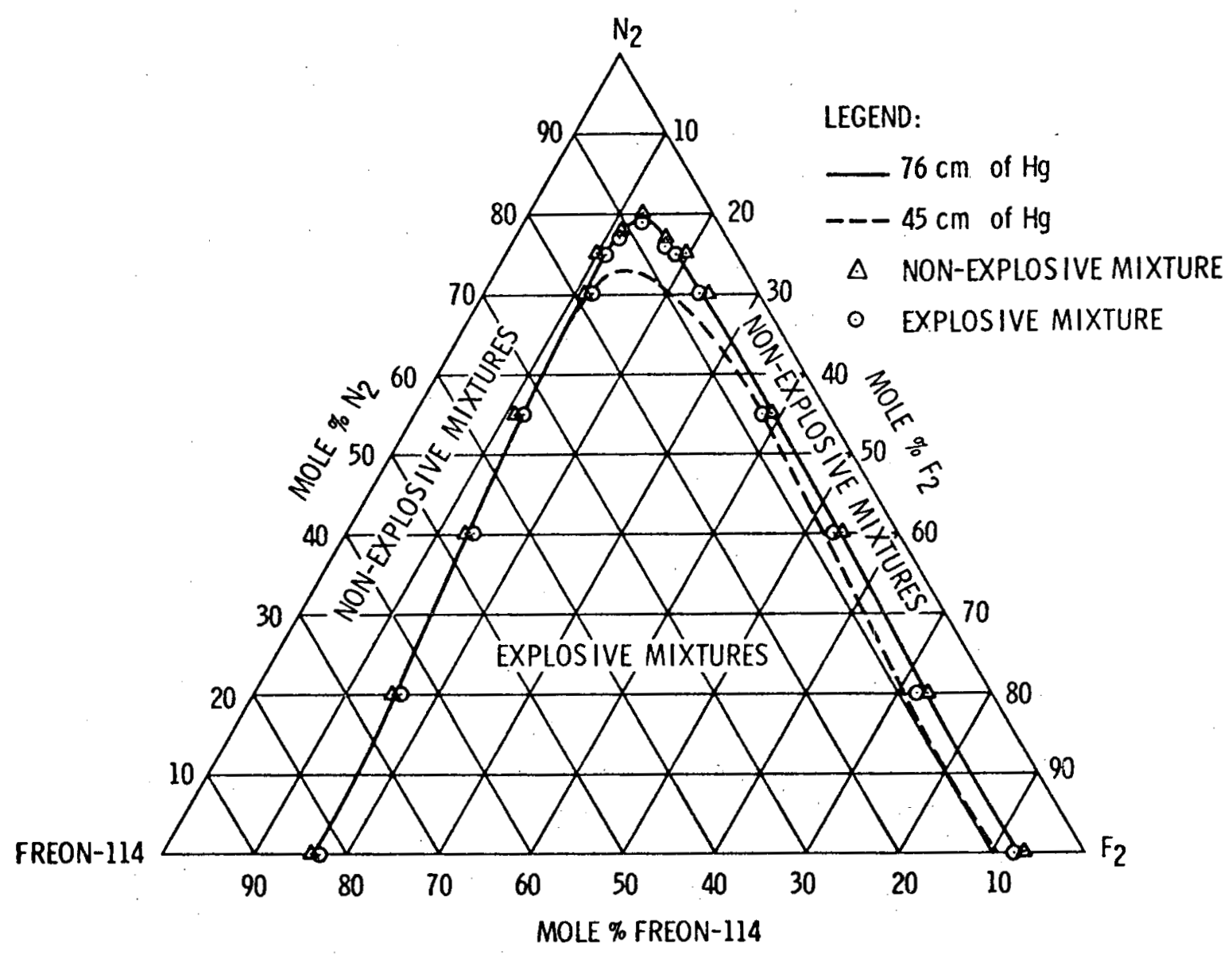

CHANGE OF COMPOSITIONAL LIMITS FOR EXPLOSION WITH PRESSURE FOR THE SYSTEM FREON-114-FLUORINE-NITROGEN AT $107^{\circ} \mathrm{C}$

Figure 29 
DWG. NO. G-66-658

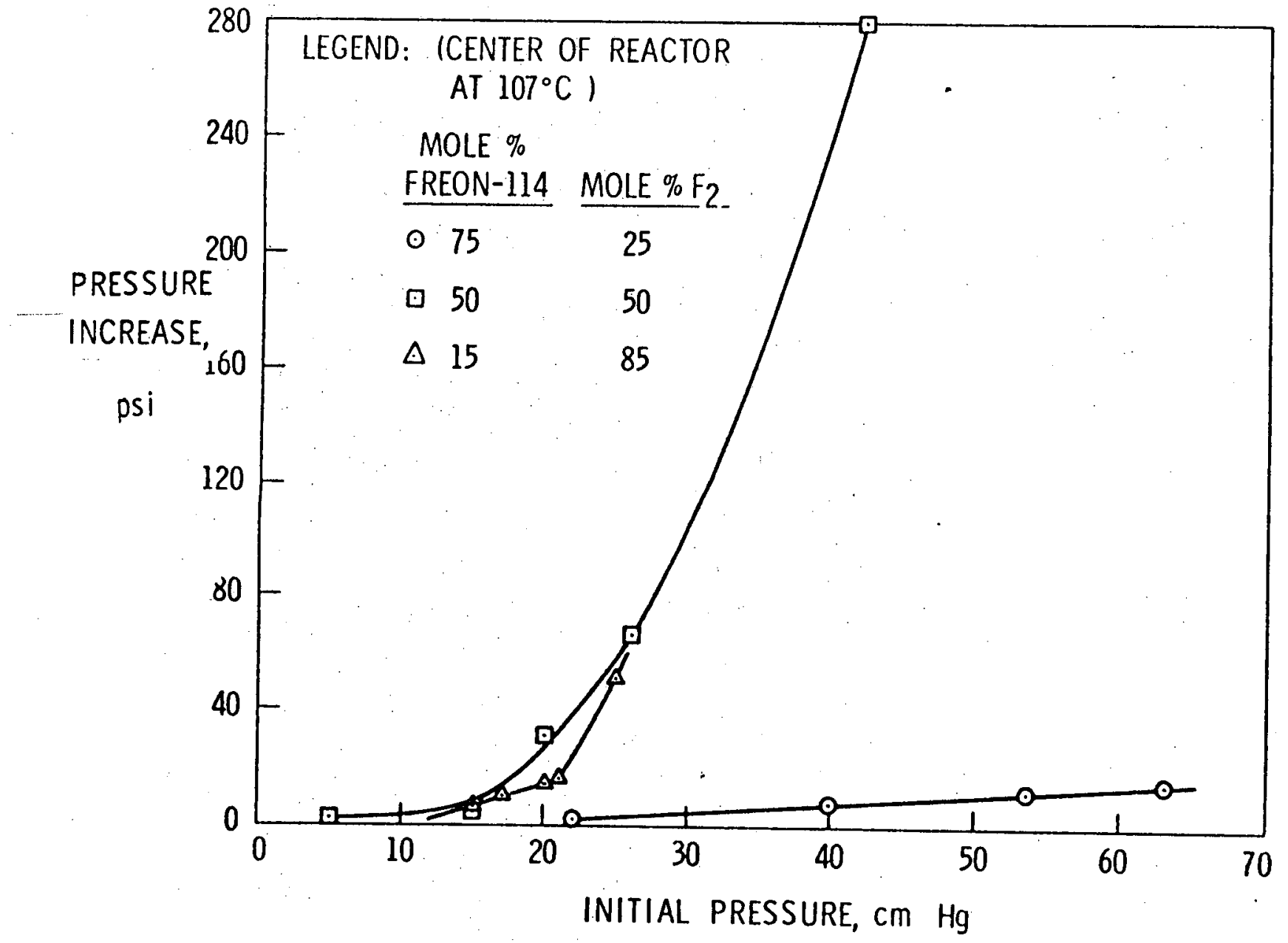

SHOCK WAVE PRESSURE AS A FUNCTION OF INITIAL PRESSURE AND COMPOSITION 
Case Histories of Lab Scale Explosions

In the May 17, 1965 issue of Chemical and Engineering News an article appeared entitled "ClF $3-K e l$ F Mixture Explodes Violently." This mixture of $\mathrm{ClF}_{3}$ in a liquid halocarbon was being disposed of by being placed outside in an open container to evaporate. It was snowing at the time (before the contents had completely evaporated) and apparently the reaction of the snow crystals with $\mathrm{C} 1 \mathrm{~F} 3$ provided enough heat to trigger the explosive mixture, again the hazardous potential of ice crystals.

The next two Figures, 31 and 32, show the debris from a small 1aboratory explosion at ORGDP which resulted from the inadvertent collection of both $\mathrm{ClF}_{3}$ and ice in a liquid nitrogen-cooled cold trap. No injuries resulted from the explosion, but possibly this was only because it occurred after work hours as the cold trap began to warm up. The explosion resulted from failure to completely remove the water from the soda lime trap before placing it into service. Chlorine trifluoride was collected in - the cold trap as designed. The water entered inadvertently, apparently by back streaming from the soda lime trap after the system was thoroughly evacuated and the experiment was stopped for the night.

\section{CONCLUSION}

In conclusion, we have reviewed the properties of fluorine and some of the more common fluorinating agents. We have emphasized the need to plan experiments and operations so as to avoid the known hazards of these materials. There will always be an element of risk in handling these materials but our objective will always be to keep this risk acceptably low. There is plenty of energy available in the very reactive materials to cause catastrophic reactions. 


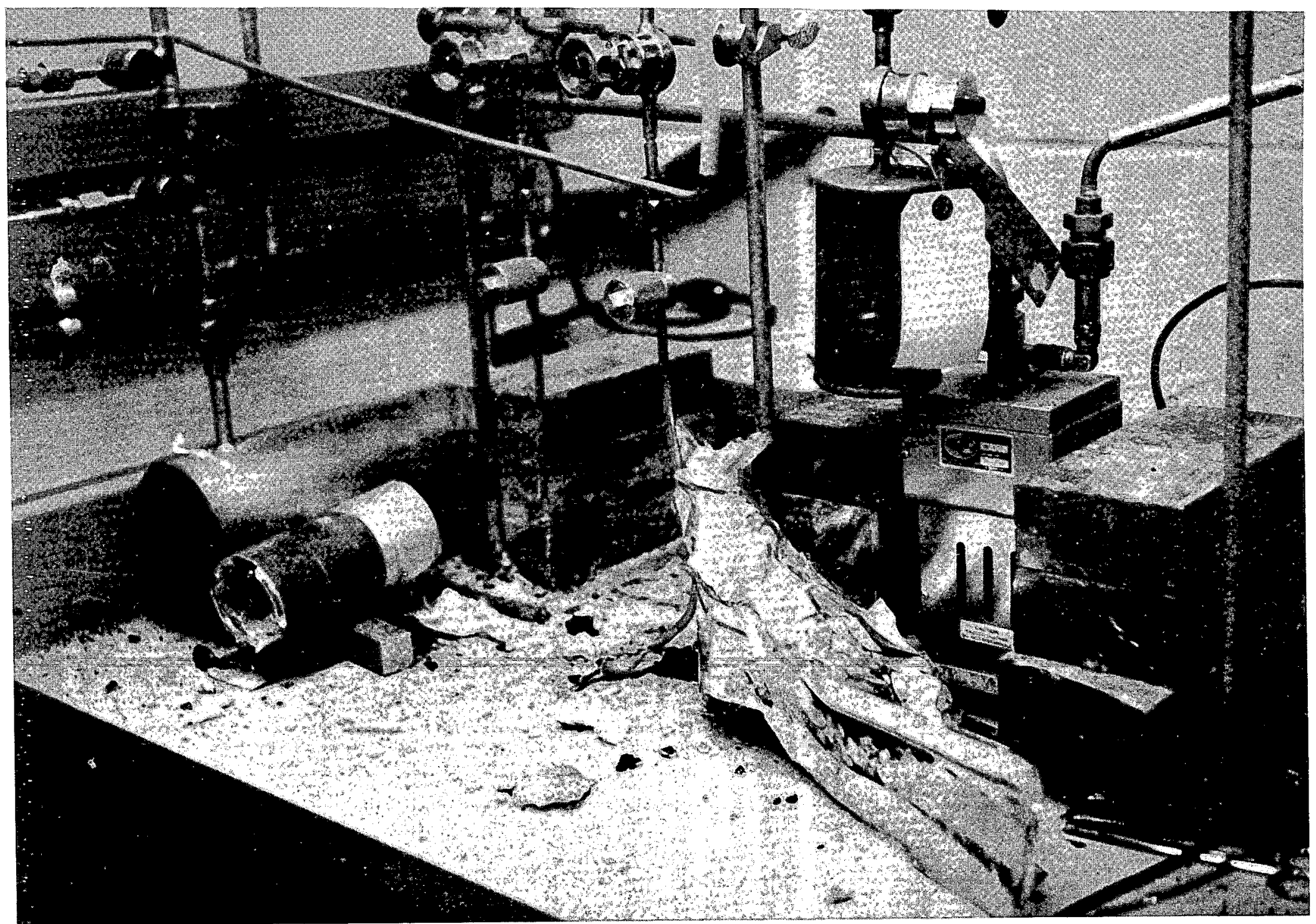

Figure 31 




Figure 32

RUPTURED COLD TRAP 


\section{SELECTED BIBLIOGRAPHY}

A. Fluorine, Chemical and Physica1 Properties

1. Mellor's Comprehensive Treatise on Inorganic and Theoretical Chemistry, Supplement II, Part I, F, Cl, Br, I, At, Longmans, Green and Co., London (1956).

2. Ryss, I. G., The Chemistry of Fluorine and Its Inorganic Compounds, Technical Information Service, United States Atomic Energy Commission, Oak Ridge, Tennessee, 2 Volumes (1956). A translation from a publication of the State Publishing House for Scientific, Technical, and Chemical Literature, Moscow, 1956.

3. Simons, J. H., Ed., Fluorine Chemistry, Vol. I, Academic Press, New York (1950). (Also Volumes II through V.)

B. Safe Handling

1. Farrar, R. L., Jr., Safe Handling of Chlorine Trifluorides and The Chemistry of the Chlorine Oxides and Oxyfluorides, Union Carbide Corporation, Nuclear Division, Oak Ridge Gaseous Diffusion Plant, November $11,1960(\mathrm{~K}-1416) . *$

2. Gordon, J., and Holloway, F. L., "Handling Gaseous Fluorine and Chlorine Trifluoride in the Laboratory," Industrial and Engineering Chemistry, 52 (5), 63A-69A (May 1960).

3. Matheson Gas Data Book, The Matheson Company, 4th Ed. (1966); Fluorine pp 237-242; Chlorine Trifluoride pp 111-115; Bromine Trifluoride pp 45-49; Bromine Pentafluoride pp 41-44; Hydrogen Fluoride pp 273-277.

4. McGuffey, J. R., Paluzelle, R. and Muldrew, W. E., "Handling Gaseous Fluorine in Industry," Industrial and Engineering Chemistry, 54 (5), 46-50 (May 1962).

5. Schmidt, H. W., Handling and Use of Fluorine and Fluorine-Oxygen Mixtures in Rocket Systems, U. S. Government Printing Office, Washington, D. C., 1967 (NASA-SP-3037).

6. Siegmund, J. M., "Production, Handling, and Shipping of Elemental Fluorine," Chemical Engineering Prog., 62 (6), 88-92 (June 1967). 
C. Corrosion

1. Corrosion Resistance of Nickel-Containing Alloys in Hydrofluoric Acid, Hydrogen Fluoride, and Fluorine, International Nickel Company, 1968 (CEB-5).

2. Hale, C. F., Barber, E. J., Bernhardt, H. A., and Rapp, K. E., High Temperature Corrosion of Some Metals and Ceramics in Fluorinating Atmospheres, Union Carbide Corporation, Nuclear Division, Oak Ridge Gaseous Diffusion Plant, September 30, 1960 (K-1459).*

3. Singleton, A. H., Tompkins, J. R., Jr., Kleinberg, S., and Sterner, C. J., "Corrosion of Metals by Liquid Fluorine," Industrial and Engineering Chemistry, 57 (3), pp 47-53 (March 1965).

D. Explosive Situations

1. Bernhardt, H. A., Hale, C. F., and Barber, E. J., Explosive Reactions Produced by Spark Ignition on Mixtures of Fluorine with Fluorocarbons and Chlorofluorocarbons, Union Carbide Corporation, Nuclear Division, Oak Ridge Gaseous Diffusion Plant, (K-L-6154-R); paper presented at the Symposium on Joint Chemistry and Technology of Fluorine and Fluorinated Compounds, at a joint meeting of AIChE, IChE, and CSChE, Montreal, Canada, September 1968.

2. "ClF $3-\mathrm{Kel}-\mathrm{F}$ Mixture Explodes Violently," Chemical and Engineering News, 43, pp 41-42 (May 15, 1965).

E. Toxicology and Industrial Hygiene

1. Threshold Limit Values for Chemical Substances in the Work Room Environment, American Conference of Governmental Industrial Hygienists (1977).

2. Hygienic Guide Series, Fluorine, American Industrial Hygienic Association, p 624-627 (Revised 1964).

3. Keplinger, M. L., and Suissa, L. W., "Toxicity of Fluorine ShortTerm Inhalation," American Industrial Hygiene Association Journa1, 29 (1), 10-18 (1968).

4. Lyon, J, S., "Observations on Personnel Working with Fluorine at a Gaseous Diffusion Plant," Journal Occupational Madicine, 4, pp 199-201, (1962).

5. Ricca, P. M., "Exposure Criteria for Fluorine Rocket Propellants," Arch. Environ. Health, 12, pp 399-407 (1966). 
6. Ricca, P. M., "A Survey of the Acute Toxicity of Elemental Fluorine," American Industrial Hygiene Association, J., 1970, 31 (1), pp 22-29.

7. Rickey, R. P., "Decontamination of Large Liquid Fluorine Spills," U. S. Air Force Flight Training Command, Tech. Report 59-21 (1959).

F. Disposal of Fluorine by Caustic Scrubbing

1. Liimatainen, R. C., and Mecham, W. J., Removal of Halogens, Carbon Dioxide, and Aerosols from Air in a Spray Tower, Argonne National Laboratory, February 28, 1955 (ANL 5429).

* Avallable from: Clearing House for Federal, Scientific and Technical Information, Department of Commerce, National Bureau of Standards, Springfield, Virginia. 